\title{
Law Enforcement Efforts Reducing Flood Risk in Palembang City
}

\author{
Azhar Azhar ${ }^{1}$ \\ \{azhar@fisip.unsri.ac.id $\left.{ }^{1}\right\}$ \\ ${ }^{1}$ International Relations Department, Universitas Sriwijaya, Jalan. Palembang- Prabumulih \\ Km32, Ogan Ilir 30662, South Sumatra, Indonesia.
}

\begin{abstract}
This paper aims to identify law enforcement in the city of Palembang, analyze the performance of officials in granting permits to transfer the function of wetlands to land built, and examine law enforcement in an effort to reduce flood risk. The the explanatory survey was used in this study. The sampling technique was done in random sampling. Data was processed descriptively, and also qualitative and quantitative analysis. This study carried out through observation, in-depth interviews, documentation and audio visual. The result shows that there are still exists a legal vacuum, the lack of commitment of authorities in enforcing the law relating to the reduction of the risk of flooding, lack of facilities and infrastructure landfills and drainage, the lack of culture dispose of waste in place and the lack of public awareness of the risk of flooding.
\end{abstract}

Keywords: law enforcement, efforts, flood risk.

\section{Introduction}

The constitution 1945 indicate that the enforcement of environmental laws in the articles relating to human rights. One of the articles is article 28 paragraph 1 of the constitution 1945 stated as follows [1]:

"Everyone has the right to live in physical and spiritual prosperity, to live, and to get a good and healthy environment and the right to get health services".

The above article is the basis that the environment must be important in the context of the protection of human rights in Indonesia. Thus, enforcement of environmental law is an important element in the protection of human rights. It is expected that with the enforcement of environmental law in the community so that it is capable and empowered to adapt to offset changes in the development process, which includes economic, social, cultural and ecological/ environmental aspects. One of the impacts of development related to ecological aspects is the phenomenon / event of flooding.

In recent decades, flood events have increased globally [2]. As a result, an increase in the incidence of flooding also has an impact on the risks that must be accepted by the community in terms of physical, social and economic aspects, such as the destruction of infrastructure, constraints on economic activities, loss of livelihoods, and not a few fatalities. The International Federation of Red Cross (IFRC) (2010) noted that among other types of natural disasters, flooding is a disaster that causes the most severe losses and damage. Floods have a direct impact on an average of 99 million people per year worldwide from 2000 to 2008. In 
fact, [3] noted that there were 178 million people who were directly affected by the flood disaster in 2010. The total losses caused by floods from 1998 to 2008 reached US $\$ 40$ trillion [4].

As a center for social and economic growth from the local to the global level, urban areas are one of the areas on the surface of the earth that are vulnerable to floods. This is caused by social and economic activities of the community, such as rapid population growth, growth in economic activities, environmental degradation, and the process of urbanization in urban areas that are not supported by adequate urban planning and management [5].

The risk of flooding increases with the emergence of slums in urban flood plains, densely populated settlements without catchment areas, and inadequate urban drainage capacity. Besides that, there are also factors of environmental change on a global scale such as increasing extreme rainfall, erratic periods of the rainy season, increasing frequency of extreme storms, and others. This contributes to the magnitude of the risk of flooding in urban areas [6].

Compared to other Southeast Asian countries, Indonesia has large cities with more dynamic flows of urbanization, increased economic activity, and rapid growth in population proportions, such as Jakarta, Bandung, Medan and Surabaya [7]. In some cities in Indonesia, land conversion efforts are also carried out by hoarding wetlands, such as swamps and peatlands, with dry land to expand the built-up area, such as housing, commercial, infrastructure, and / or agricultural land. wetland landfill or reclamation efforts are commonly found in cities on the island of Sumatra and Borneo Island, such as Pekanbaru, Jambi, Palembang, Pontianak and Banjarmasin [8].

In fact, several studies have shown that the existence of wetlands can be a function of retention and filtration of water, local climate regulators, urban biodiversity habitats and prevention of flooding [9]. As a flood controller, vegetation in wetland ecosystems can capture and release surface water and rainwater. This vegetation can also reduce the speed of flood water in flooded areas. Reduced wetlands in the flood plains of the city of Lagos (Nigeria) due to changes in the function of land into slums from 1986 - 2006 resulted in the emergence of floods in this area, such as in 2002 and 2006 [10].

Thus the conversion of land becomes a threat to the existence of swamps, dry land in the country especially in the city of Palembang. The city of Palembang is undergoing a change in wetlands to function as land built along with the development in the city of metropolis. The development of Palembang City shows that there is a change in wetlands in the form of swamps to be built up land which causes a continuous reduction in the amount of swamps in Palembang City [11]. Changes that occur in the form of the construction of housing, commercial centers, factories and government centers [12].

Urgency of this research is to find law enforcement by strengthening the licensing, supervision, taking action to change the wetlands become awakened area to prevent flooding.

\section{Law Enforcement Theory}

According to Black law dictionary interpreted the act of putting something as a law into effect, the execution of a law. While law enforcement officer means that those whose duty it is to preserve the peace. [13]. In the Kamus Besar Bahasa Indonesia [14], enforcers are the ones who establish, enforce. Law enforcers are those who enforce the law, in the narrow sense only means the police and prosecutors which are then expanded to include judges, lawyers and prisons. 
Furthermore, according to Soerjono Soekanto [15]. law enforcement is an activity that harmonizes the relationship of values outlined in the values/ views that are firm and manifests them in action as a series of final stages of value translation to create, maintain and maintain life's social peace. Concrete law enforcement is the enforcement of positive law in practice as it should be obeyed. Therefore, giving justice in a matter means deciding the law in concreto in maintaining and guaranteeing the obedience of material law by using procedures stipulated by formal law [16].

Josep Golstein [16] (Muladi, 1995: 40), distinguishes criminal law enforcement into 3 parts, namely: Total enforcement, namely the scope of criminal law enforcement as formulated by substantive law of crime. Enforcement of criminal law in total is not possible because law enforcers are strictly limited by criminal law, which includes, among other things, the rules for arrest, detention, search, confiscation and preliminary examination. Besides that, it is possible that the substantive criminal law itself provides limitations, for example, a complaint is required as a condition for prosecution of complaint offenses (klacht delicten). This restricted scope is called the area of no enforcement; Full enforcement, after the total scope of criminal law enforcement is reduced by the area of no enforcement in law enforcement, law enforcers are expected to enforce the law maximally; Actual enforcement, is considered not a realistic expectation, because there are limitations in the form of time, personnel, investigative tools, funds and so on, all of which lead to the necessity of discretion and the rest is what is called actual enforcement.

Law enforcement is also divided into two, seen from the subject and object [18]. From the point of view of the subject, the law can be divided into two, namely in the broadest sense and in the narrow sense. In a broad sense, the law enforcement process involves all legal subjects in every legal relationship. Anyone who runs normative rules or does something or does not do something by basing himself on applicable legal norms means that he runs or enforces the rule of law. Whereas in a narrow sense, law enforcement is only interpreted as an attempt by certain law distinguish enforcement agencies to guarantee and ensure that a rule of law runs as it should.

Whereas when viewed from the point of the object, namely in terms of the law itself can be hed in the broad sense and in the narrow sense. In a broad sense, law enforcement encompasses the values of justice which contain the formal rules and values of justice that exist in society. In a narrow sense, law enforcement is only concerned with enforcing formal and written regulations.

According to Soejono Soekanto [19] there are several factors that influence law enforcement such as its own legal, namely legislation; law enforcement, the parties forming and applying law, facilities to support the enforcement of law, community, namely the environment in which the law applies or applies, cultural factors, namely as a result of work, creativity, and a sense that is based on human intention in life.

First the legal factor itself. Because in the implementation of the implementation of law in the field there are times when there is a conflict between legal certainty and justice, this is due to the conception of justice is an abstract formulation, while legal certainty is a normatively determined procedure.

Thus, a policy or action that is not entirely based on law is something that can be justified as long as the policy or action is not against the law. Then in essence the implementation of law does not only include law enforcement, but also peace maintenance, because the administration of law is actually a process of harmonization between values and real behavior patterns that aim to achieve peace. 
In practice we see that there are laws and regulations that are mostly obeyed and there are also laws that are not obeyed. The legal system clearly collapses if everyone does not comply with the laws and regulations and the legislation loses its meaning. No the effectiveness of laws and regulations tends to influence the timing of attitudes and quantity of non-compliance and has a real effect on legal behavior, including behavior of lawbreakers. This condition affects law enforcement which guarantees certainty and justice in the community.

Second, the factor of law enforcement officials, namely those who form and implement laws that include motivation, competence of law enforcement officers, mentality or personality of law enforcement officers play a very important role. Although the existing regulations are good, if law enforcement officials do not have competence in their field of work, do not have good motivation and mentality or corrupt personality and are not trustworthy and dishonest, then it is not possible to enforce the law as expected. Therefore, one of the keys to success in law enforcement is the competence, motivation, mentality and/ or personality of the law enforcer concerned. In addition to the number or ratio of law enforcement officers there is not enough standard.

The third factor is facilities supporting law enforcement. The facilities include software (Soft skills) and hardware (Hard skills), one example of software is science, education and competence in their field. Education and training received by law enforcement officers today tends to be practically conventional. So that in many ways law enforcement officers experience obstacles in their duties. Among them are knowledge about knowledge of environmental governance, computer crime, in special criminal acts which have been given authority to the public prosecutor. This is because technically the juridical law enforcement officers are considered not yet capable and not ready. Although it was also realized that the tasks that must be carried out by law enforcement officers are so wide and numerous. While hardware includes buildings, equipment, operational costs and inadequate salaries.

The fourth factor is the community where law enforcement officers come from the community and aim to achieve peace in the community and environment where the law applies or is applied. Every citizen or group has a little legal awareness, the problem that arises is the level of legal compliance, namely compliance law that is high, medium, or lacking. The existence of a degree of community legal compliance with the law in the environment where the law is valid or applied, is one indicator of the functioning of the law concerned.

Finally, cultural is a result of work, creativity, and taste based on human intention in life. Based on the concept of everyday culture, people often talk about culture. Culture according to Soerjono Soekanto, has a very large function for humans and society, namely regulating so that people can understand how they should act, act, and determine their attitude if they relate to other people.Thus, culture is a basic line of behavior which establishes rules regarding what must be done, and what is prohibited.

\section{Method}

\section{a. Questionnaires}

This research design is the approach of quantitative and qualitative collaboration. The consideration was that this approach would provide more detailed, comprehensive, and objective analysis instruments. The data were collected by disseminating the questionnaire toward 475 respondents in Palembang city through random sampling, in-dept interviews, focus group discussion, and observation. The primary and secondary data were analyzed and 
interpreted according to the main aim of this research. In the analysis, some displays are presented in the form of tables, graphs, and narratives.

\section{b. Population and Sample}

The study population is who lives in Palembang city. In order to represent the Palembang population entire, the study involved only 475 respondents in seeking view on law enforcement's effect on reducing flood risk. The study is randomly selected respondents from 14 sub-districts in Palembang City, namely sub-districts Ilir Timur I, Ilir Timur II, Seberang Ulu I, Ilir Barat I, Ilir Barat II, Sukarami, Sako, Kemuning, Kalidoni, Bukit Kecil, Gandus, Alang-Alang Lebar, Sematang Borang, and Kertapati.

\section{c. Data Analysis}

For quantitative data were analyzed descriptively, presented in tabular form and analyzed retained earnings depth. In addition, qualitative analysis is also conducted, which can reach the substance of the problem and problem solving.

\section{Result and Discussion}

If we look at the data (Table 1) below, there is a regulatory vacuum in the execution of the main tasks of the Palembang City Service function such as measures for handling river water resources (watershed) and sub-rivers controlling water, provision of food agriculture land protection and empowerment of fish farming farmers, regulations for structuring industrial space planning and controlling air pollution.

The environmental regulation on irrigation affairs and management of the river basin in Palembang is indicated by a regulatory vacuum, even though the regulations related to it are like the regional regulations of South Sumatra Province numbers 21/2010 and 5/2013), government regulations numbers 20/2006 and 38/2011 , and laws numbers 11/1974 and $37 / 2014$ are already available (table 1 point 2 ) so that it is not surprising if there is always accumulation of tributaries and / or water-carrying canals by people of various interests. If the landfill activity is not immediately managed properly and integrated, it will cause excess water (flooding) during the rainy season and drought during the dry season and the impact of the vulnerable to public health problems due to stagnant water.

Thus the effort to manage the watershed properly by synergizing development activities is very much needed not only for the sake of maintaining production capacity or the economy, but also the efforts to reduce flood risk.

The Environmental Regulation of Palembang City's Sustainable Food Agriculture $(P L P 2 P B$ in Indonesian Language) land protection also indicates a regulatory vacuum. Even though the regulations related to it such as the regional regulations of South Sumatra Province number 21/2014, government regulations number 1/2011, and laws number 41/2009 is available (table 1 point 3). Palembang City's sustainable food agriculture is a system and process in planning and establishing, developing, utilizing and fostering, controlling and supervising food crops and their area in a sustainable manner.

Increasing population growth and urbanization and economic and industrial developments have resulted in degradation, conversion and fragmentation of agricultural land into built-up land. This will contribute to excess water (flooding) in the city of Palembang.

Based on the findings in the field that the apparatus involved in the field of flood prevention in Palembang City is the Government of Palembang City, which consists of various agencies such as: Civil Service Police Unit (Sat-Pol PP), SARS Team of 
Palembang City, Palembang Constructioan and Housing (PUPR) Office, Sub-District Head, and Lurah (head of village).

Whereas law enforcement officers have the duty to enforce the law in the field of flood risk mitigation based on Government Regulation No.16 of 2018 concerning Civil Service Police Unit Article 5 point A) Civil service units enforce Regional Regulations and Head of Regional Regulations; Point B) Carrying out public order and peace ; and point $\mathrm{C}$ ) carry out community protection.

The findings shows that the number of law enforcement officers enforcing Regional Regulations relating to flood risk amounted to 553 (five hundred fifty three) people. Viewed by Group consists of: 4 people in groups IV, 95 groups III, 89 groups II and 5 groups I. While based on the level of education, 9 people have master degree (S2) in education, 72 people have undergraduate degree (S1) in education, Diploma 1(D1) to Diploma 3(D3) 9 people, Upper Middle School as many as 98 people and 5 people are high school. According to staffing status, it consists of 193 Civil Servants, 353 contract employees and 3 freelancers.

Furthermore, the Civil Service Police Unit faces various obstacles to enforce the law in efforts to mitigate flood risk. In enforcing the local regulation concerning building permit/permission to build a building (IMB), they faced individuals behind the IMB violators such as examples of cases, Palembang Icon buildings on POM IX street and hotel building on Letkol Iskandar street

In addition, in terms of law enforcement against the Waste Management Regulations, there are no adequate facilities and infrastructure available. So that people throw carelessly like empty land and river watersheds. Then for the facilities and infrastructure consists of software (soft skills) and hardware (hard skills), for the software the majority of employees do not yet have the competence about flooding. As for the hardware, there are still findings in the field that many do not have an adequate garbage disposal station. It is proven that the lack of garbage disposal facilities causes people to be confused to dispose of garbage, so that garbage is disposed inappropriate places.

To overcome the risk of flooding, the city government of Palembang launched a regional regulation on the transfer of wetland functions into dry / built land, namely by stockpiling wetlands such as swamps and peatlands with dry land. In addition, in controlling floods, the government believes through this effort it can also expand the built area, such as housing, commercial, infrastructure, and/ or agricultural land. However, based on the percentage of Palembang people who respond to the policy of shifting the function of wetlands (swamps) to dry land is disagree.

Table 1. Function of Office Affairs Related to Environmental Regulations

\begin{tabular}{|c|c|c|c|c|c|}
\hline \multirow[b]{2}{*}{ No. } & \multirow[b]{2}{*}{$\begin{array}{c}\text { Description of Environmental } \\
\text { Regulations }\end{array}$} & \multicolumn{4}{|c|}{ Availability of Regulations } \\
\hline & & Act & $\begin{array}{l}\text { Government } \\
\text { Regulations }\end{array}$ & $\begin{array}{c}\text { Provincial } \\
\text { Regulat- } \\
\text { ions }\end{array}$ & $\begin{array}{c}\text { City } \\
\text { Regula- } \\
\text { tions }\end{array}$ \\
\hline \multirow[t]{2}{*}{1} & Spatial planning. & $26 / 2007$ & $15 / 2010$ & & \\
\hline & Spatial plans. & & & $11 / 2016$ & $15 / 2012^{]}$ \\
\hline 2 & Soil and water conservation. & $37 / 2014$ & $43 / 2008$ & & \\
\hline
\end{tabular}


Irrigation.

Management of water resources.

Irrigation .

Management of watersheds.

Guidance and supervision of liquid waste disposal.

$3 \quad$ Sustainable food agriculture land protection

Development of swamp control and utilization.

4 Fishery;

Protection and empowerment of fishing farmers and fish cultivators 5 Industry;

Industrial business permit;

Industrial development plan.

6 Forestry;

Prevention and eradication of forest destruction

Control of forest fires and / or land

City Forest.

7 Protection and management of the environment.

Sustainable development;

Waste management;

Conservation of living natural resources and ecosystems Air pollution control.
$11 / 1974$

$81 / 2001$

$42 / 2008$

$20 / 2006$

$38 / 2011^{[11]}$

21/2010 - O -

$82 / 2001$

- O -

$26 / 2011$

$41 / 2009$

$1 / 2011$

$21 / 2014$

- O -

$73 / 2013$

- O -

$11 / 2012$

$45 / 2009$

$60 / 200$

$5 / 2017$

- O -

3/2014 ]

$107 / 2015$

$18 / 2017$

- O -

41/1999 63/2002

18/2013 45/2004 [

$4 / 2001$

$8 / 2016$

$63 / 2002$

$27 / 2012$

$17 / 2016$

6/2007

$32 / 2009^{3}$

(7)

$81 / 2012$ [ 20/2014 $\quad 3 / 2015$

$5 / 1990$

$41 / 1999$

- O -

Information: - $\bigcirc$ - regulatory vacuum

Source: BAPPEDA (Planning Agency) of Palembang City

Regarding to the findings that the possibility of the local community has been alert to the transfer of the function of wetlands (swamps) to dry land. Dry land is effective for development purposes, such as housing, mall and industry, but in the future it will exacerbate floods, not control them. Even against the procedures of licensing construction in Palembang also as much as $48 \%$ of respondent disagree, and most others namely $34 \%$ still undecided.

The community disagree with the idea of the city government to rebuild from the results of wetland utilization (swamps), but if the community is associated with regulations in flood control in Palembang, the percentage of people who agree to increase to $20 \%$ states that they agree that regulations provide more attention to the issue of flooding in their city.

Concerning to the supervision of development permits, $29 \%$ of respondents said they did not agree to the supervision of development permits, $19 \%$ agreed, only $4 \%$ expressed enthusiasm that they strongly agreed to supervise the construction permit, while the remaining $42 \%$ were hesitant. It can be concluded that not many agreed to the decision to supervise the 
construction permit, and the respondents who were hesitant were also quite large in expressing their uncertainty whether the policy was good or not for them.

The community provides an assessment of the performance of employees making development permits. The number of doubtful respondents occupies the largest percentage (43\%)compared to respondents who agree that the performance is good, and do not agree that the performance of the employees in question is good $(36 \%)$.

The respondents doubts about the policy of transferring wetlands (swamps) to dry land, whether it will be effective as a flood control solution in Palembang, or even worsen it. In graph 6.5 the number of respondents stated that they doubt (43\%) about the staff competency of the building permit (IMB). This shows that they were hesitant about the efforts to transfer wetlands (swamps) to dry land would be good for their life gaps, but they still put high trust that the apparatus assigned to enforce the law in an effort to reduce flood risk in their area is competent and has sufficient knowledge to bring good change to the city of Palembang $(42 \%)$.

Regarding whether the government is committed to the issue of flood prevention, based on the respondent's assessment, the government's commitment in preventing floods is still not good enough. Respondents' assessment of the government's commitment was $43 \%$ not committed, $36 \%$ agree $7 \%$ considered the government strongly not committed, $37 \%$ unsure (hesitant), $16 \%$ stated that the government was quite committed, and $4 \%$ said the government was strongly committed.

According to Soerjono ${ }^{[4]}$, one of the factors that influence law enforcement is availability or facilities that support law enforcement. In the case of law enforcement in an effort to reduce the risk of flooding in the city of Palembang, the availability of supporting facilities or facilities such as culverts, drainage, plaster, and retention ponds is very important. Based on the survey conducted, data were found as follows:

Data shows, $48 \%$ of respondents said that facilities or facilities such as culverts, drainage, plaster, and retention ponds in their environment were still inadequate. And $11 \%$ of the states that facilities or facilities in handling flood risk are available.

Availability of facilities and facilities such as culverts, drainage, plaster, retention ponds should function properly. So that the risk of flooding can be minimized. However, based on the survey conducted, $30 \%$ of respondents stated that supporting facilities such as culverts, drainage, plaster and retention ponds in their environment were not functioning properly, and $19 \%$ said the facilities were not functioning properly. However, $20 \%$ of respondents stated that these facilities functioned well, and $5 \%$ stated that they functioned very well. The rest is doubtful whether culverts, drainage, plaster and retention ponds in their environment are functioning properly or not.

Apart from the availability of culverts, drainage, plaster and retention ponds in the community, the availability of adequate landfills is also very important. Report from Chief environmental services and City Cleanliness Palembang stated that in one day, the volume of waste produced from household and industrial waste can reach one thousand $(1,000)$ tons. The high level of waste production is not comparable with the availability of landfills. This is acknowledged by respondents that $59 \%$ waste disposal place is inadequate in their area.

In addition to the availability of supporting facilities or waste disposal place, there are also community factors, namely the environment in which the law applies (Soerjono Soekanto. 2004: 42-43). This is related to community compliance with the law itself. For example, does the Palembang community dispose of garbage in its place or not. Based on City Regulation number 3 of 2015 concerning Household and Similar Waste Management, that 
anyone who disposes of waste not in its place will be subject to a maximum criminal sanction of 6 months or a fine of 50 million rupiah. However, based on the survey, it was found data that the level of community compliance to dispose of garbage in its place is still very low $(15 \%)$. And very few respondents stated that they had disposed of garbage in its place. So that people dispose or litter, such as on the roadside or in the river. For example what happened in the some sub-district in Palembang City close to the Ampera Bridge (Picture 3).

Community factors are also related to community legal knowledge and compliance. Here the researchers also asked the level of knowledge of the community regarding the distribution of the city of Palembang, for example knowledge of wetland areas in the city of Palembang, $73 \%$ respondents knew. The respondents knowledge of water catchment areas (which are prohibited areas of settlements) in the city of Palembang, for this question $63 \%$ of respondents stated that they knew that.

In an effort to find solutions to the law enforcement in reducing the risk of flooding in Palembang City, researchers also included questions related to whether people in Palembang live in wetland areas and whether the residence of the community has permits in accordance with the regional regulations of Palembang City. From the survey results, it was found that $59 \%$ of the population lived in wetland areas and $93 \%$ had building permits for their homes.

In addition, a cultural factor, that is as a result of work, creativity and a sense that is based on human intention in social life [20]. Culture is a behavior of the community that develops into a habit, both bad habits and good habits, which later becomes a common habit and developed in the community or also called culture. An example is the culture of Palembang community related to disposing of garbage.

This research also raises questions to see the importance of the culture of disposing of garbage for the people of Palembang City. From the survey results it was found that respondents agreed that dumping garbage in place is very important $95 \%$. There are only $3 \%$ of respondents say that disposing of garbage in its place is an unimportant action. In addition, $2 \%$ of respondents were hesitant about their attitude regarding the importance of disposing of garbage in its place. The survey results show that there are still people in the city of Palembang who are indifferent to the importance of disposing of garbage in its place. So that the government needs to provide socialization regarding the importance of disposing garbage in its place.

This awareness is also related to the culture of disposing garbage in the community. A good culture related to disposing of garbage is putting garbage in its place, for example in trash cans or places that have been determined by the government. In big cities like Palembang, the availability of adequate waste disposal sites is a must. So there is no reason for the community not to throw garbage not in its place or even in the river. The river is often used as a community as a garbage dump, especially people who live near the river.

From the survey results it was found that $7 \%$ of respondents often disposed of garbage in the river, $11 \%$ said they had, $32 \%$ said they never, $35 \%$ said they never dumped garbage at the river. The remaining $15 \%$ were doubtful whether they had even thrown up in the river or not.

The data above shows that there are still many people in Palembang who have a habit of throwing garbage in the river, this also shows the attitude of disobedience to the community regarding the rules regarding landfills in accordance with the regulations of the Palembang city government.

The picture 3 shows the condition of the Musi river filled with garbage. The lack of public awareness of the importance of disposing of garbage in its place. The habit of people who dispose of garbage not in its place becomes a bad habit that is considered a common thing in the community itself. 


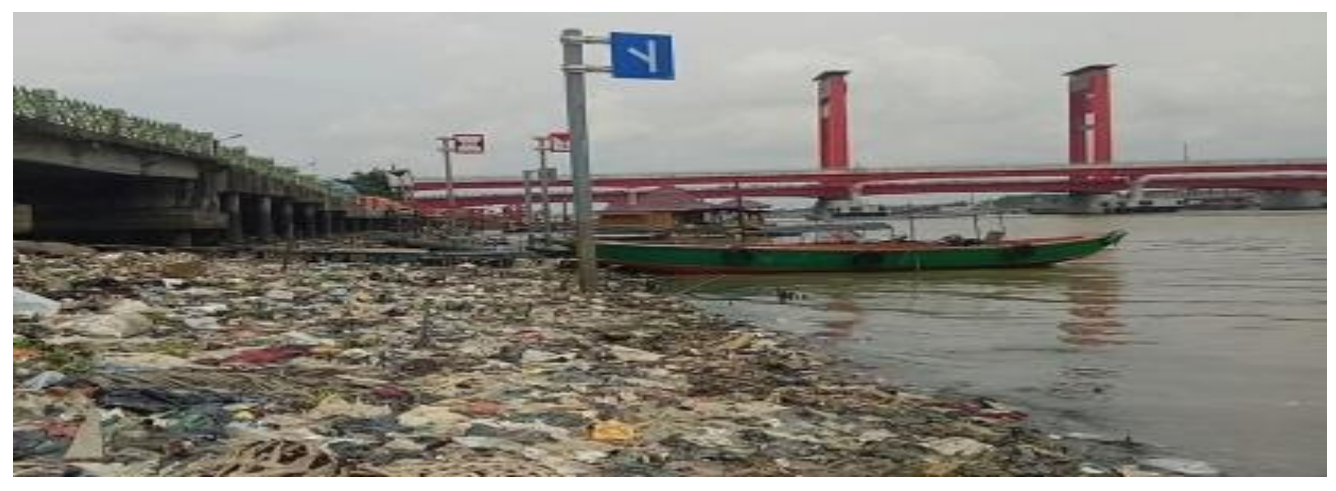

Fig 1. Musi river filled with garbage

Source: Private photo of researcher

This culture is also related to the culture of mutual cooperation owned by the Indonesian Nation. Mutual cooperation is a form of practice from the fifth principle of five principles (Pancasila), which is a form of mutual assistance between fellow humans. In this case it can be seen how the mutual cooperation culture of the Palembang community in maintaining the cleanliness of their living environment. The environment of residence is the property and shared responsibility. So that cleanliness, safety and comfort are the responsibility of all people who live in the environment. From the survey results, it was found that $71 \%$ of respondents often worked together, $10 \%$ never, $3 \%$ never, the rest were undecided.

\section{Conclusion}

This study shows that Regional Regulation on Licensing the Transfer of Wetland (Swamp) Function to Dry Land by the government is ineffective efforts to control flood problems in Palembang city.

Regarding Building Permits, almost half of the Palembang city population lived in wetlands (swamps), and the rest lived in dry areas, and the average majority had obtained permits for the buildings they occupied. This shows that the government's commitment to the issue of flood prevention is not good enough. The fact is that the function of wetlands (swamps) into settlements is careless actions which actually result in the emergence of floods and result in settlements becoming slums. This is because vegetation in the wetland ecosystem can function to capture and release surface water and rainwater, so that the flood can be controlled. Vegetation is also able to reduce the speed of flood water in flooded areas. Decreasing wetlands causes flooding to worsen in an area.

In addition to government policy, the culture of maintaining the cleanliness of the community in 14 sub-districts in the city of Palembang which was used as the location in this study had a very large contribution to the problem of flooding. Field surveys show a very large percentage of people who do not orderly dispose of garbage in its place, almost half of the community is aware that disposing of garbage in its place is very important for their survival and flood risk in their area. On the other hand, half of the people who do not care and still throw trash not properly

There is still a pile of rubbish that is mounting in the community settlements, showing how badly it is processing waste. Disposable waste is also a category of waste that is difficult 
to recycle, and consequently settles in rivers around the settlements . This ultimately worsened the face of the city of Palembang itself. When the rain comes, the condition of the streets, settlements in the city becomes floods.

Acknowledgments. The authors gratefully acknowledge that the present research is supported by Sriwijaya University in Competitive Research Skim of Year 2018 .

\section{References}

[1] Constitution, Constitution 1945, 1945.

[2] IFRC, „, World Disaster Report 2010: Focus On Urban Risk, “International Federation of Red Cross and Red Crescent Socitie, Geneva, 2010.

[3] A. Jha, R. Bloch a J. Lamond, Cities and flooding: a guide to integrated urban flood riskmanagement for 21st Century, World Bank Publications, 2012.

[4] A. Jha, T. Minner a Z. Z. G. Stanton, Building Urban Resilience: Principles, Toolsand Practice,, The World Bank, 2012.

[5] I. Adelekan, „Vulnerability assessment of an urban flood in Nigeria: Abeokuta flood 2007,“ Natural Hazards 56(1), pp. 215-231., 2011.

[6] R. Findrabe, M. Arima, S. Inoue a B. Kada, Analyzing flood risk and related impacts to urban communities in central Vietnam. Mitigation and Adaptation Strategies for Global Change, 2012.

[7] H. Wang, P. Kuo a J. Shiau, ,Assessment of climate change impacts on floodingvulnerability for lowland management in southwestern Taiwan, “Natural Hazards, 68(2), pp. 1001-1019, 2013.

[8] P. Guhathakurta, O. Sreejith a P. Menon, „Impact of climate change on extreme rainfalleventsand flood risk in India,“ Journal of Earth System Science, 120(3), pp. 359373., 2011.

[9] K. Trenberth, „Framing the way to relate climate extremes to climate change, “ Climatic Change, 115(2), pp. 283-290, 2012.

[10] D. Coumou a S. Rahmstorf, „A decade of weather extremes,“ Nature Climate Change, 2(7), pp. 491-496, 2012.

[11] S. Rowe a G. Villarini, „Flooding associated with predecessor rain events over the MidwestUnited States,“ Environmental Research Letters, 8(2), 2013.

[12] G. Jones, „Southeast Asian Urbanization and The Growth of MegaUrban Region,“ Journal of Population Research, 19(2), pp. 119 -136, 2002.

[13] C. Pulungan, „Fauna Ikan dari Sungai Tenayan, Anak Sungai Siak, dan Rawa di Sekitarnya,“ Riau.Berkala Perikanan Terubuk, 37(2), pp. 78-90, 2009.

[14] A. Sa'ad, S. Sabiham, A. Sutandi, B. Sumawinata a Ardia, „Perubahan Penggunaan 
Lahan Pasang SUrut Setelah Reklamasi di Delta Berbak, Jambi,“ Jurnal HRpolitan, 1(3), pp. 37 - 46., 2010.

[15] H. Khaliesh, I. Widiastuti a S. B. Budi, Karakteristik Permukiman Tepian Sungai Kampung Beting di Pontianak: Dari Rumah Lanting ke Rumah Tiang, 2012.

[16] D. Dahliani, „Konsep Pengolahan Tapak Permukiman di Lahan Rawa, Banjarmasin.,“ Lanting Journal of Architecture 1 (2), pp. 96 - 105., 2012.

[17] V. Lantz, P. Boxall, M. Kennedy a J. Wilson, „The valuation of wetland conservation in anurban/peri urban watershed.," Regional Environmental Change, pp. 1-15, 2013.

[18] H. Jia, H. Ma a M. Wei, „Urban wetland planning: A case study in the Beijing central region," Ecological Complexity, 8(2), pp. 213-221, 2011.

[19] D. Kim, S. Kim a T. Ahn, ,Wetland Construction: Flood Control and WaterBalance Analysis.," Environmental Engineering Research (EER), 15(4):, pp. 197-205., 2010.

[20] J. Birkmann, M. Garschagen, F. Kraas a N. Quang, ,Adaptive urban governance: newchallenges for the second generation of urban adaptation strategies to climate change,“ Sustainability Science, 5(2), pp. 185-206, 2010.

[21] S. Sagala, Dodon, D. Lutfiana a R. Wimbardana, Alih Fungsi Lahan Rawa dan Kebijakan Pengurangan Risiko Bencana Banjir: Studi Kasus Kota Palembang, 2013.

[22] B. A. Garner, Black Law Dictionary, St. Paul: West Publicing, 1999.

[23] Departemen Pendidkan dan Kebudayaan, Kamus Besar Bahasa Indonesia, Jakarta : Balai Pustaka, 1998.

[24] S. Soekanto, Faktor-faktor yang Mempengaruhi Penegakan Hukum, Jakarta: PT. Raja Grafindo Persada, 2005.

[25] S. Dellyana, Konsep Penegakan Hukum, Yogyakarta: Liberty , 1998.

[26] Muladi, Kapita Selekta Sistem Peradilan Pidana, Semarang: Undip, 1995.

[27] A. M. T. a. S.-G. Z. Jha, Building Urban Resilience: Principles, Toolsand Practice, The World Bank, 2012. 